\title{
Rany klatki piersiowej i serca w pracach Dominika Jeana Larreya
}

\section{Chest and heart wounds in the works of Dominique Jean Larrey}

\section{Summary:}

This text raises the problem of the beginning of procedures performed in the early nineteenth century on the pericardial sac, and especially punctures in the event of fluid buildup. Thus, he presents the contribution of Dominique Jean Larrey to the foundations for later cardiac surgery.

Słowa kluczowe: Dominique Jean Larrey, Francisco Romero, rany serca, nakłucie osierdzia, chirurgia XIX w.

Keywords: Dominique Jean Larrey, Francisco Romero, heart wounds, pericardial puncture, 19 th century surgery

Spuścizna naukowa Dominika Jeana Larreya, wybitnego chirurga epoki napoleońskiej, jest bardzo obszerna i wielokierunkowa. Dlatego gdy zapoznaje się $\mathrm{z}$ nią podczas gromadzenia danych do biografii ${ }^{1}$ tej postaci, o której Napoleon wyraził się, iż był to ,jedyny człowiek, któremu mogłem zaufać”", trudno nie zauważyć, że cały szereg ważkich

${ }^{1}$ M.J. Turos, Dominique Jean Larrey (1766-1842), „Napoleon V”, Oświęcim 2017.

2 M.J. Turos, Człowiek, któremu mogłem zaufać (Napoleon Bonaparte). Jan Dominik Larrey i jego misja w czerwcu 1813 roku, w: Studia nad epoka napoleońska, t. I, „Napoleon V”, Oświęcim 2014, s. 186. 
tematów będzie wręcz domagać się oddzielnego, szerszego i bardziej wnikliwego opracowania. Jednym z nich są zagadnienia dotyczące urazów klatki piersiowej i serca. Jest to tym bardziej istotne, że w literaturze przedmiotu dominują na ogół krótkie, hasłowe przyczynki połączone z dyskusją o pierwszeństwie wykonania konkretnego zabiegu, jak uczynili to w swoich publikacjach Harris Shumacker ${ }^{3}$ oraz Imre Toth $^{4}$, bądź też przekłady fragmentów prac oryginalnych, niejednokrotnie dokonywane już z tłumaczeń, nie zaś francuskiego oryginału, pozbawione dłuższego komentarza, a opatrzone jedynie krótkim wprowadzeniem odautorskim, sygnalizującym trudną dostępność tekstu źródłowego na terenie Polski ${ }^{5}$. Spośród biografów jedyne szersze omówienie zagadnienia zamieścił w swojej pracy John H. Dible, poświęcając mu liczący siedem stron akapit ${ }^{6}$.

Temat urazów klatki piersiowej, z którymi stykał się praktycznie bez przerwy w czasie kampanii wojennych, w jakich uczestniczył, poczynając od 1792 r., a także możliwości postępowania w przypadku ran penetrujących w okolicę serca, był dla Dominika Jeana Larreya ważki i interesujący. W odniesieniu do tego drugiego rodzaju obrażeń nie krył się z tym, iż wielu wybitnych lekarzy powątpiewało w podejmowane przez niego działania, a tym bardziej nie akceptowało wyrażanego nowatorskiego i obrazoburczo brzmiącego w owym czasie poglądu, którym podważał powszechnie wyrażaną opinię, że „rany serca i worka osierdziowego są absolutnie śmiertelne i właśnie dlatego też postępowanie z nimi nie mieści się w granicach sztuki lekarskiej"7. Jeśli już padło takie zdanie, to wymagało bardzo szczegółowego oraz dokładnego uzasadnienia. I zostało ono dokonane, przede wszystkim w pracach, które Larrey publikował od początku XIX w. Ich doniosłość, w pełni nowatorski charakter, a zarazem pierwszeństwo podkreśla zapis na oficjalnej stronie internetowej powołanego do istnie-

${ }^{3}$ H. Shumacker, When did cardiac surgery begin?, „Journal of Cardiowasc. Surgery” 1989, nr 30, s. 246-249.

${ }^{4}$ I. Toth, R. Rami-Porta, Sz. Rendeki, T.F. Molnar, First steps in the Management of Pericardial Effusion: Who Was the First to Relieve the Pericardial Sac - Larrey or Romero, ,World Journal of Surgery” 2013, nr 37, s. 2242-2245.

${ }^{5}$ W. Stembrowicz, Dominique Jean Larrey (1766-1842) - autor pracy o ranach worka osierdziowego, „Archiwum Historii i Filozofii Medycyny” 1995, nr 58, z. 3, s. 311-328. Autor przekładu posłużył się tu wersją niemiecką: D.J. Larrey, Chirurgische Klinik eine Sammlung in den Feldzügen und Militärhospitä,lern von 1792 bis 1829, t. I, Leipzig und Darmstadt 1831, s. 351-377.

${ }^{6}$ J.H. Dible, Napoleon's Surgeon, „William Heinemann Medical Books”, London 1970, s. 253-259.

7 D.J. Larrey, Clinique chirurgicale exercée particulièrement dans les camps et les hôpitaux militaires, depuis 1792 jusqu'en 1829, t. II, Ed. Gabon, Paris 1829, s. 175. 
nia w 2002 r. Polskiego Towarzystwa Kardio-Torakochirurgów ${ }^{8}$ oraz wiele innych ${ }^{9}$.

Sama opinia dotycząca nietykalności serca nie była wypowiedzią jednorazową, lecz powszechnie panującym na przełomie XVIII i XIX w. poglądem, że klatka piersiowa jest obszarem zamkniętym przed chirurgiem dla wszystkich jego działań. Najlepszym na to dowodem są wydawane podówczas prace gromadzące dorobek najwybitniejszych medyków. Na terenie Francji, ojczyzny Larreya, warto przede wszystkim sięgnąć do prac jego bezpośredniego nauczyciela Raphaëla Bienvenu Sabatiera. W drugim tomie swej obszernej De la medecine operatoire..., pierwszy raz opublikowanej w $1796 \mathrm{r}^{10}$, pisał o usuwaniu ropy nagromadzonej w klatce piersiowej ${ }^{11}$, odwołując się do obserwacji Marchettisa i LeDrana (nazwiska w brzmieniu wg tekstu z $1822 \mathrm{r}^{12}$ ), czy ciała obcego tkwiącego w mostku, lecz nigdzie nie wspominał ani słowem o ranach penetrujących $\mathrm{w}$ tej okolicy anatomicznej bądź też o ranach serca.

Warto $\mathrm{w}$ tym miejscu nadmienić, że w podobny sposób pisał Józef Czekierski. W drugim tomie swojej Chirurgii... ${ }^{13}$ zranieniom klatki piersiowej poświęcił obszerny rozdział liczący 10 paragrafów, gdzie omówił m.in. krwawienie $\mathrm{z}$ tętnic międzyżebrowych, a nawet uszkodzenie samej tkanki płucnej, lecz o sercu - leżącym przecież w klatce piersiowej i wraz z jej strukturami tak samo narażonym na skutki ura$\mathrm{zu}$ - nie ma tam najmniejszej wzmianki.

Skąd więc Dominique Jean Larrey mógł zasięgnąć informacji bądź co stanowiło podstawę jego wiedzy? Bez wątpienia, prócz innych, o których jeszcze będzie mowa w dalszej części tekstu, było to dzieło Huguesa Ravatona Chirurgie d'armée ou traité des plaies d'armes à feu, et d'armes blanches... ${ }^{14}$, który temu zagadnieniu poświęcił liczący osiem stron rozdział zatytułowany Des contusions de la poitrine ${ }^{15}$. Prócz zajęcia się obrażeniami struktur powierzchownych, wspomniał

\footnotetext{
${ }^{8}$ https://ptkt.pl/historia-polskiej-kardiochirurgii/ [dostęp: 15.04.2020].

9 Tu m.in. https://kardiochirurgiadziecieca.cm-uj.krakow.pl/historia/wazne-datyhistoryczne-w-kardiologii/ [dostęp: 15.04.2020].

${ }_{10}$ R.B. Sabatier, De la médecine opératoire, t. I, Ed. Bechet Jeune, Paris 1822, s. XV.

${ }_{11}$ R.B. Sabatier, De la médecine opératoire, t. II, Ed. Bechet Jeune, Paris 1824, s. $432-438$.

12 Tamże.

${ }_{13}$ J. Czekierski, Chirurgii przez Jóżefa Czekierskiego, t. II, Drukarnia przy Nowolipiu, Warszawa 1818, s. 1-21.

${ }^{14} \mathrm{H}$. Ravaton, Chirurgie d'armée ou traité des plaies d'armes à feu, et d'armes blanches, Ed. Didot, Paris 1768.

15 Tamże, s. 27-35.
} 
również, co prawda bardzo ogólnikowo, o możliwości, w przypadku głębszych zranień, uszkodzenia worka osierdziowego. Podał przy tym opisy trzech przypadków z własnej praktyki, jednak zranienia dotyczyły jedynie ścian klatki piersiowej i mostka.

Czy podobne przypadki zdarzały się i innym chirurgom? Bez wątpienia tak, lecz traktowane były na zasadzie kazuistycznej, ewentualnie prezentowane na posiedzeniach naukowych przede wszystkim w paryskiej l'Academie deChirurgie ${ }^{16}$, o czym wspomina E. Rumebe de Suech, wymieniając lekarza o nazwisku Faudacq, który omawiał przypadek rany postrzałowej klatki piersiowej połączonej z uszkodzeniem płuca ${ }^{17}$. Brak jest tutaj bliższych danych bibliograficznych, ale przypuszczalnie chodziło tu o akapit „Des Playes d'armes a Feu de la Poitrine”, zamieszczony jako $\$ 111 \mathrm{w}$ drugim tomie Mémoires de l'Académie royale de chirurgie ${ }^{18}$, w którym o podobnym przypadku wspomina też chirurg o nazwisku Gerard bądź Geraud ${ }^{19}$. Wiadomości te rzadko były jednak ewidencjonowane w sposób szczegółowy czy szerzej opracowywane. Tu dobrym materiałem może być Encyclopedie Methodique ${ }^{20}$ Felixa Vicq-d'Azyra, pomijająca owo zagadnienie zupełnym milczeniem. Informacje o innych pracach, często bardzo rozproszonych, jak chociażby znaleziony już po śmierci autora tekst Jeana Louisa Petita, w którym podzielił urazy klatki piersiowej na dwie kategorie: drążące i powierzchowne ${ }^{21}$, zamieścił w swojej Dissertation sur les plaies d'armes a feu penetrantes dans la poitrine ${ }^{22}$ wzmiankowany już E. Rumebe de Suech. Nie bez znaczenia jest, że pełne wydanie prac Petita, o którym wspomina, ukazało się dopiero blisko 40 lat po jego śmierci w $1790 \mathrm{r}^{23}$, zaś akapit ten, o czym nie omieszkał również wspomnieć E. Rumebe de Suech, powtórzył później m.in. Piere François Percy ${ }^{24}$, cytując dla odmiany jeden z obszerniejszych tekstów Godfreda Bidloo ${ }^{25}$.

${ }^{16}$ E. Rumebe de Suech, Dissertation sur les plaies d'armes a feu penetrantes dans la poitrine, Ed. Didot Jeune, Paris 1814, s. 16.

17 Tamże.

${ }^{18}$ Mémoires de l'Académie royale de chirurgie, Ed. Delaguette, Paris 1753, s. 512-514.

19 Tamże, s. 512.

${ }^{20}$ F. Vicq-d'Azyr, Encyclopédie méthodique, médecine, par une société de médecins. CO-ENV, Ed. Pancoucke, Paris 1792, s. 30.

${ }^{21}$ E. Rumebe de Suech, dz. cyt., s. 7.

${ }^{22}$ Tamże, karta tytułowa.

${ }^{23}$ J.L. Petit, Traité des maladies chirurgicales : et des opérations qui leur conviennent, Ed. Méquignon l'aîné, Paris 1790.

${ }^{24}$ E. Rumebe de Suech, dz. cyt., s. 10.

${ }^{25}$ Przypuszczalnie chodziło tu o traktat G. Bidloo, Opera omnia anatomico-chirurgica, S. Luthmans, Lugduni Batavorum 1715. 
Sam E. Rumebe de Suech omówił w swojej pracy cztery przypadki zranień klatki piersiowej, z którymi zetknął się w swojej praktyce chirurgicznej, i których leczenie zakończyło się powodzeniem. Miejsca uszkodzenia były jednak każdorazowo dość odległe od serca i dotyczyły przestrzeni między trzecim a czwartym żebrem oraz okolic prawego obojczyka ${ }^{26}$. Warto również nadmienić, iż jego rozprawa została zadedykowana Dominikowi Jeanowi Larreyowi jako bezpośredniemu nauczycielowi, z którego doświadczeń wiele skorzystał w czasie jej przygotowywania ${ }^{27}$.

Sam Larrey po raz pierwszy o urazach klatki piersiowej pisał obszerniej $\mathrm{w}$ swoich notatkach prowadzonych podczas kampanii egipskiej 1798-1801, które uporządkował po powrocie do Francji i zamieścił w tomie zatytułowanym: Relation historique et chirurgicale de l'armee d'Orient en Egypte et en Syrie par D-J. Larrey ${ }^{28}$, opublikowanym w Paryżu w 1803 r. W „sekcji VIII”, gdyż takim mianem określał kolejne rozdziały swojego liczącego ponad 400 stron dzieła, znaleźć można, co prawda niezaznaczony bezpośrednio w samym tekście, ale zasygnalizowany w odpowiedni sposób w spisie treści, akapit zatytułowany „rany drążące klatki piersiowej połączone z krwawieniem”29.

Akapit ów, liczący dziewięć stron ${ }^{30}$, zawiera uwagi odnośnie do postępowania $\mathrm{w}$ tego rodzaju zranieniach, które najczęściej kończą się śmiercią z powodu samej rozległości urazu oraz masywnego krwawienia i uszkodzenia płuc. Nie należało jednak powstrzymywać się od podejmowania działań $w$ celu uratowania rannego, i tu na poparcie swojej tezy przytoczył dwa przypadki. Pierwszy dotyczył szeregowca, któremu cios szabli otworzył klatkę piersiową między czwartym a piątym żebrem, drugi zaś podoficera kawalerii rannego w okolicę szóstego żebra, również ciosem broni siecznej. Larrey zaznaczył, iż i u jednego, i u drugiego doszło do uszkodzenia płuc, gdzie „wraz z krwią wydobywały się pęcherzyki powietrza" ${ }^{31}$. Czynności, które każdorazowo podejmował, koncentrowały się na oczyszczeniu i zbliżeniu brzegów rany oraz pokryciu całej powierzchni odpowiednio dopasowanym, lepkim plastrem, a następnie ścisłym założeniu bandaży z płótna. Obydwaj pacjenci przeżyli, przy czym u pierwszego kuracja

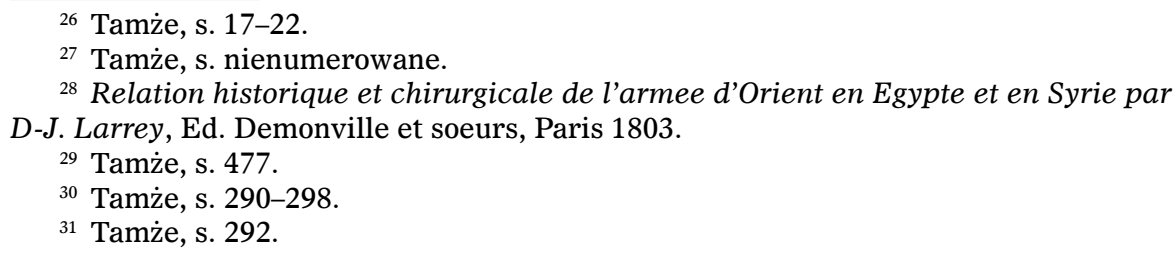

${ }^{26}$ Tamże, s. 17-22.

27 Tamże, s. nienumerowane.

${ }^{28}$ Relation historique et chirurgicale de l'armee d'Orient en Egypte et en Syrie par D-J. Larrey, Ed. Demonville et soeurs, Paris 1803.

${ }^{29}$ Tamże, s. 477.

30 Tamże, s. 290-298.

31 Tamże, s. 292. 
trwała względnie krótko, gdyż w okresie „12 Vendémiaire - 20 Brumaire"32, czyli od 3 października do 10 listopada. Co do określenia roku, gdy doszło do tych zdarzeń, zachodzi pewien problem, ponieważ tekst zachowanego oryginału ${ }^{33}$ jest $\mathrm{w}$ tym miejscu nieczytelny.

Trzeba tutaj wspomnieć, że podobny przypadek dotyczący zranienia nożem między piątym a szóstym żebrem, w okolicy mostka, opisał Ludwik Perzyna ${ }^{34}$. Po poszerzeniu rany klatki piersiowej odsłonił serce, ucisnął starannie miejsce uszkodzenia oraz wytamponował worek osierdziowy, pokrywając ranę dużym opatrunkiem i dodatkowo jeszcze „plastrem lipkim”35. Te pierwsze działania, jak i późniejsze postępowanie przyniosły pożądany skutek i po dość długiej kuracji ranny żołnierz powrócił do zdrowia. Biorąc pod uwagę, że do zdarzenia tego mogło dojść w 1791 bądź 1792 r., był to najprawdopodobniej pierwszy przypadek na świecie.

Warto w tym miejscu zwrócić także uwagę na środki opatrunkowe. Używane podówczas powszechnie plastry określane potocznie mianem „lipkich”36, nasączone woskiem bądź specjalną mieszanką żywic pochodzenia roślinnego (były to głównie biała żywica sosnowa, wyciągi $\mathrm{z}$ terpentyny oraz gumożywica galbanowa ${ }^{37}$ ), a także surowego wosku, doskonale spełniały tu swoje zadanie, izolując jamę klatki piersiowej od przedostawania się powietrza z zewnątrz, zarazem pozwalały na uchodzenie tego, które gromadziło się w jamie opłucnej, i można je śmiało uznać za prototyp stosowanego współcześnie w warunkach polowych tzw. opatrunku Aschermana ${ }^{38}$. Wymienia je w swojej wielotomowej Narzadu opatrzenia chirurgicznego Rafał Józef Czerwiakow-

32 Tamże. Był to okres, kiedy posługiwano się we Francji tzw. kalendarzem republikańskim wprowadzonym decyzją Konwentu 5.10.1793 r. Tu za: Ch. Cook, J. Stevenson, Leksykon nowożytnej historii Europy 1763-1999, Warszawa 2000, s. 63.

${ }^{33}$ Bibliotheque Nationale de France, http://gallica.bnf.fr/ark:/12148/bpt6k9690743x [dostęp: 24.11.2019].

${ }^{34}$ L. Perzyna, Nauki cyrulickiey krótko zebraney..., t. III, w Drukarni J.O.Xcia Prymasa Arcy-Biskupa Gnieźnieńskiego, w Kaliszu 1793, s. 128-134.

${ }^{35}$ Tamże, s. 130.

${ }^{36}$ R.J. Czerwiakowski, Narzadu powszechnego opatrzenia chirurgicznego czéść III, Kraków 1816, s. 13.

${ }^{37}$ Wyciąg z rośliny o nazwie zapaliczka galbanowa rosnącej na Bliskim Wschodzie. Tu za: D.J. Mabberley, Mabberley's Plant-Book, Cambridge University Press, Cambridge 2017, s. 362.

${ }^{38}$ P. Kluj, M. Dąbrowski, T. Sanak, A. Dąbrowska, M. Sip, T. Gaszyński, Specyfika udzielania pomocy medycznej poszkodowanemu w warunkach bojowych $w$ środowisku taktycznym w oparciu o standard TCCC. Część IV: Zaopatrywanie obrażeń klatki piersiowej podczas wykonywania zabiegów ratowniczych $w$ środowisku taktycznym w oparciu o standard TCCC, „Anestezjologia i Ratownictwo” 2014, nr 8, s. 106-118. 
ski, a „plastrom pospolitych rannych” ${ }^{39}$ poświęcił specjalny rozdział zatytułowany przez siebie „wydziałem”40, obejmujący 33 paragrafy, przy czym wyróżnił wiele ich kształtów i rodzajów właściwych dla danej okolicy anatomicznej, na której miały zostać zastosowane, oraz typu zranienia. Tej tematyce, prócz wspomnianego zapisu tekstowego, poświęcił również dwie plansze w kończącym dzieło tomie VII ${ }^{41}$. Prócz wosku jako substancji klejącej, szczególnie omawiając plastry tzw. angielskie ${ }^{42}$, którymi zbliżano brzegi rozległych ran, w tym niejednokrotnie po amputacjach, Rafał Józef Czerwiakowski wspominał również o „karuku”43, czyli o specjalnym „kleiu rybim”44.

W czasie kampanii egipskiej Dominique Jean Larrey, będąc bacznym obserwatorem otoczenia, zwrócił również uwagę na wiele żywic używanych w Egipcie i na Bliskim Wschodzie od czasów starożytnych, nie tylko do balsamowania zwłok ${ }^{45}$. Ze względu na zawartość olejków eterycznych, m.in. mirry ${ }^{46}$ oraz wyciągów $\mathrm{z}$ aloesu ${ }^{47}$, wykazywały one pewne działanie antyseptyczne i tym samym przyspieszały proces gojenia rany. Niewątpliwie stosował cały szereg spośród tych substancji, gdyż o opatrunkach z plastrów doskonale chroniących rany przed wpływem klimatu wielokrotnie wspominał $\mathrm{w}$ swojej pracy, przede wszystkim w akapicie poświęconym amputacjom ${ }^{48}$.

Technika nakładania ścisłych opatrunków, zarówno unieruchamiających złamane żebra, jak i stosowanych w przypadkach zranień klatki piersiowej, zaczęła być w tym czasie również dość rozpowszechniona, do czego szczególnie na terenie Francji przyczynił się przede wszystkim wydany w 1799 r. atlas ${ }^{49}$ kończący dwutomową Encyclo-

${ }^{39}$ R.J. Czerwiakowski, dz. cyt., s. 17.

${ }^{40}$ Tamże, s. 17-45.

${ }^{41}$ Narzadu powszechnego opatrzenia chirurgicznego część VII. Tabele przez Rafała Czerwiakowskiego, br. m. wyd. br. daty. Biblioteka Jagiellońska w Krakowie określa go mianem tomu oddzielnego, zawierającego tablice i wydanego ok. 1817 r. W bibliografii autorstwa K. Estreichera jest on zaznaczony jako dzieło bez tytułu. Tu za: K. Estreicher, Bibliografia polska XIX wieku, t. III, wyd. II, Drukarnia Narodowa, Kraków 1963, s. 522.

${ }^{42}$ R.J. Czerwiakowski, dz. cyt., s. 28.

${ }^{43}$ Klej otrzymywany z pęcherzy pławnych wielu gatunków ryb, https://pl.wikipedia. org/wiki/Karuk [dostęp: 21.11.2019].

${ }^{44}$ R.J. Czerwiakowski, dz. cyt., s. 28.

${ }^{45}$ Relation historique et chirurgicale..., dz. cyt., s. 416 i nast.

46 P. Dolara, Analgesic effects of myrrh, „Nature” 1996, nr 379(6560), s. 29.

${ }^{47}$ E. Cieślik, K. Turcza, Właściwości prozdrowotne aloesu zwyczajnego Aloe vera (L.) Webb. (Aloe barbadensis Mill), „Postępy Fitoterapii” 2015, nr 2(16), s. 117-124.

${ }^{48}$ Relation historique et chirurgicale..., dz. cyt., s. 435-437.

${ }^{49}$ Encyclopédie méthodique, chirurgie, par une société de médecins. Recueil des planches du dictionnaire de chirurgie Paris : H. Agasse, An VII. (1799) Planche XXI. 
pédie méthodique, chirurgie, par une société de médecins ${ }^{50}$ autorstwa Daniela LaRoche i Philippe’a Petita-Radela, która ukazała się w latach 1790-1792 w Paryżu.

Temu zagadnieniu poświęcał również dużo uwagi Rafał Józef Czerwiakowski, wyróżniając kilka sposobów bandażowania klatki piersiowej, o czym pisał w powstałej ok. 1804 r. Chirurgii praktycznej ${ }^{51}$ - dziele funkcjonującym w licznych odpisach, które samo pozostawało w manuskrypcie aż do połowy XX w. Jako najbardziej przydatne w takich sytuacjach wymieniał: „łopatkową noszącą obwiązkę” oraz „obwiązkę pancerzową"52. Podobnie w drugim tomie Narzadu opatrzenia chirurgicznego ${ }^{53}$ w rozdziale zatytułowanym „opaski tułowia” ${ }^{54}$ wyodrębnił liczący siedem stron akapit poświęcony wyłącznie opatrunkom klatki piersiowej i wymienił w nim kolejno trzy sposoby nakładania bandaży, od strony praktycznej odwołując się jednocześnie do wzmiankowanego już ostatniego tomu swojego dzieła, zamieszczającego odpowiednie ryciny. Rozpoczyna je plansza opatrzona numerem XXIII, gdzie znaleźć można jedną „figurę" zakładany w przypadku zranień w okolicy mostka. Temat ten rozwinął oraz poszerzył na kolejnych planszach, a mianowicie: XXIV, XXVI i XXVII tu szczególnie istotna jest ryc. 2 przedstawiająca opatrunek typu warstwowego, który doskonale pokrywał zranienie, a co więcej, mógł nawet stabilizować klatkę piersiową po rozległych urazach - następnie zaś XXXI, co w sumie dawało doskonały obraz, a obecnie pozwala na wyrażenie poglądu, że Rafał Józef Czerwiakowski omawiał i prezentował to zagadnienie w sposób niezwykle szczegółowy.

Tematyką urazów klatki piersiowej Dominique Jean Larrey zajął się ponownie w drugim tomie swoich Memoires $^{56}$, w liczącym dziesięć stron akapicie zamieszczonym w pierwszej części zatytułowanej Kampania Egipska i Syryjska ${ }^{57}$, gdzie prócz analizy przypadków z kampa-

${ }^{50}$ Encyclopédie méthodique, chirurgie, par M. de La Roche et M. Petit-Radel. A-KYS, Panckoucke, Paris 1790, LAC-ZIG. Table des matières, explications des planches, Panckoucke, Paris 1792.

51 Grzelak E. (opr.), Chirurgia praktyczna Rafała Józefa Czerwiakowskiego, wyd. MON, Warszawa 1969.

52 Tamże, s. 240-241.

${ }_{53}$ R.J. Czerwiakowski, Narządu opatrzenia chirurgicznego część II, w Krakowie 1816.

${ }^{54}$ Tamże, s. 257-263.

${ }^{55}$ Narzadu powszechnego opatrzenia chirurgicznego część VII. Tabele przez Rafała Czerwiakowskiego, tab. 23 br. paginacji.

${ }^{56}$ D.J. Larrey, Memoires de chirurgie militaire et campagnes de D. J. Larrey, t. II, Ed. J. Smith, Paris 1812, s. 150-159.

57 Tamże, s. 1-312. 
nii egipskiej, o których pisał już uprzednio, dodał również swoje bieżące wnioski, odwołując się do dzieł Ambroise’a Paré oraz Giovanniego Vigo - niestety nie podając bliżej, o które pozycje tu chodzi, ani z których prac, szczególnie w odniesieniu do Paré, korzystał. Przypuszczalnie, jeśli wziąć pod uwagę drugiego $\mathrm{z}$ wymienionych autorów, był to traktat La practique et chirurgie... ${ }^{58} \mathrm{w}$ tłumaczeniu Nicolasa Godina, i pomimo powstania w drugiej połowie XVI w. nadal bardzo popularny w szkole medycznej w Paryżu. Cytował również inny tekst autorstwa Giovanniego Vigo Traite des plaies de poitrine ${ }^{59}$, lecz o oryginale tego dzieła brak jest bliższych wiadomości. Sięgał również do prac Valentina. $\mathrm{Z}$ podanego $\mathrm{w}$ tym samym wersie tytułu dzieła można wywnioskować, iż chodzi o Louisa-Antoine Valentina, związanego w latach 60. XVIII w. z paryskim kolegium chirurgów, gdzie m.in. opiekował się studentami przygotowującymi swoje tezy i prace egzaminacyjne $\mathrm{z}$ chirurgii i anatomii, autora Recherches critiques sur la chirurgie moder$n e^{60}$, zawierającego obszerny rozdział poświęcony zranieniom klatki piersiowej ${ }^{61}$. Nieobce mu były także najnowsze obserwacje poczynione przez Albrechta. Znów nie podaje tu więcej danych bibliograficznych, ale wszystko wskazuje na to, iż chodziło tu o Albrechta von Hallera, autora m.in. Mémoires sur la nature sensible et irritable des parties $d u$ corps animal ${ }^{62}$, opublikowanej w Lozannie w $1760 \mathrm{r}$.

Po raz kolejny obrażeniami klatki piersiowej zajął się bardziej szczegółowo i pisał o nich w trzecim tomie Memoires, gdzie m.in. omówił przypadek z bitwy pod Heilsbergiem (Lidzbarkiem Warmińskim) dotyczący obrażeń pułkownika Vrigniego ${ }^{63}$, rannego kartaczem w klatkę piersiową. Kula uszkodziła część mięśni piersiowych po stronie prawej, a także na przestrzeni ok. $8 \mathrm{~cm}$ złamała mostek, wtłaczając przy

${ }^{58}$ La practique et chirurgie de M. Iean de Vigo docteur en medecine. Divisé en deux parties: où est traicté la Cure des playes, ulcères, apostemes, \& autres maladies, desquelles le corps humain est souvent affligé. Traduict de latin en françois, par M. Nicolas Godin D. en médecine. Le tout de nouveau reveu, \& exactement corrigé, Pierre Rigaud, Lyon 1610.

${ }^{59}$ D.J. Larrey, Memoires de chirurgie militaire et campagnes de D. J. Larrey..., dz. cyt., s. 154.

${ }^{60}$ L-A. Valentin, Recherches critiques sur la chirurgie moderne, avec des lettres à M. Louis,... docteur en chirurgie... secrétaire perpétuel de l'Académie royale de chirurgie", Amsterdam 1772.

${ }^{61}$ Tamże, s. 25-40.

${ }^{62}$ Mémoires sur les parties sensibles et irritables du corps animal. Contenant les experiences de plusieurs anatomistes d'Allemagne, de France, d'Angleterre \& d'Italie. Ouvrage qui sert de suite aux mémoires de Monsieur de Haller, Sigismond d'Arnay, Lousanne 1760.

${ }^{63}$ D.J. Larrey, Memoires de chirurgie militaire et campagnes de D. J. Larrey..., dz. cyt., t. III, s. 80 . 
tym do rany fragmenty uniformu. Po usunięciu największych strzępków tkanek i innych widocznych ciał obcych, w tym także samej kuli, Larrey opatrzył ranę, o której napisał, że wyglądała bardzo poważnie, później zaś, w toku gojenia, wraz z ropą powoli wydzieliły się małe fragmenty kostne złamanego mostka ${ }^{64}$. Ten ostatni wers pozwala przypuszczać, że musiał często odwiedzać swoich pacjentów w lazaretach polowych.

Do tematu powrócił w czwartym tomie Memoires ${ }^{65}$, w którym można znaleźć dość rozbudowany, liczący osiemnaście stron akapit zatytułowany Rany klatki piersiowej ${ }^{66}$, włączony do rozdziału Kampania w Saksonii, gdzie zamieścił raport ze swoich poczynań w czasie kampanii 1812/1813. Już we wstępie znów odwoływał się do swoich uprzednich doświadczeń z praktyki, poruszając zagadnienia dotyczące właściwego wykonywania opatrunków, a także postępowania w przypadku obrzęku, który można utożsamiać z narastającą odmą podskórną. Opis takiego przypadku zawarł także w tym tomie, w rozdziale noszącym tytuł Kampania rosyjska część $I^{67}$.

Rzecz dotyczyła polskiego oficera, niestety brak tu jest bliższych danych, imienia czy nazwiska, rannego piką kozacką w okolicę lewego barku i łopatki, u którego doszło do przebicia klatki piersiowej połączonego z uszkodzeniem płuca. Jak sam pisał: „powietrze wydostawało się pod skórę i tworzyło ogromne obrzmienie" ${ }^{68}$. Larrey usunął plastry, którymi początkowo zostały zbliżone brzegi rany, w jej okolicach postawił bańki, które natychmiast wypełniły się krwią i nagromadzonym pod skórą powietrzem, następnie założył opatrunek z plastrów zwilżony winem kamforowym i ułożył pacjenta tak, by rana znajdowała się w najniższym punkcie ciała. Wewnętrznie zastosował „napar z arniki górskiej oraz wino" ${ }^{69}$. Kuracja przyniosła pozytywny skutek i jak sam wspominał, spotkał owego oficera już po zakończeniu kampanii moskiewskiej, nadmieniając: „i nawet bym go nie poznał, gdyby mi się sam nie przypomniał"70.

Kolejny przypadek dotyczył żołnierza rannego w czasie potyczki pod Mohylewem 22 lipca 1812 r. Kula uszkodziła ósme i dziewiąte żebro, po czym utkwiła w klatce piersiowej. Po opatrzeniu został on

${ }^{64}$ Tamże.

${ }^{65}$ D.J. Larrey, Memoires de chirurgie militaire et campagnes du baron D-J Larrey, t. IV, Ed. J. Smith, Paris 1817.

${ }^{66}$ Tamże, s. 250-268.

67 Tamże, s. 11-13.

${ }^{68}$ Tamże.

${ }^{69}$ Tamże.

${ }^{70}$ Tamże. 
ewakuowany do szpitala w Kownie, a następnie w Toruniu. Rana częściowo się zagoiła, ale po pewnym czasie uformował się ropień, który pękł samoistnie i wydostały się z niego strzępki tkaniny i duża ilość ropy. W 1814 r. ranny trafił do Paryża i wreszcie w 15 czerwca 1816 r. do szpitala Gros Caillou. Dominique Jean Larrey zbadał dokładnie pacjenta i stwierdził, że w tej nie do końca zagojonej ranie tkwią ciała obce i fragmenty martwej kości. W czasie operacji, którą przeprowadził w lipcu, usunął wszystkie obumarłe tkanki i dość dużą kulę rosyjską - „ważyła około uncji" "11, czyli ok. 28 gramów, była to średnia waga pocisku karabinowego ${ }^{72}$. Dalszy przebieg kuracji, choć burzliwy i powikłany krwawieniem z tętnicy międzyżebrowej, zakończył się pomyślnie. Dnia 22 sierpnia 1816 r. pacjent został zaprezentowany na posiedzeniu Societe de Medecine w Paryżu, a przebieg leczenia opisany $\mathrm{w}$ specjalnym doniesieniu, które ukazało się $\mathrm{w}$ Bulletins de la Faculte de medecine de Paris ${ }^{73}$.

Trzeci z omówionych przypadków dotyczył żołnierza, który został kontuzjowany w czasie obrony Paryża w 1814 r. Kula uderzyła w okolicę czwartego żebra tuż przy mostku i nie naruszając dużych naczyń, przebiła płuco, po czym utkwiła na wysokości ósmego-dziewiątego żebra przy kręgosłupie. Powstał rozległy ropniak, który Larrey naciął przez przestrzeń międzyżebrową w okolicy dziewiątego żebra, usunął wszystkie martwe tkanki wraz z fragmentem żebra oraz kulę. Dalszy przebieg kuracji był pomyślny, lecz niestety po czterech miesiącach od zabiegu pacjent zmarł na skutek zatrucia alkoholem ${ }^{74}$.

Warto zwrócić uwagę, że w szczegółowym skorowidzu obejmującym wszystkie tomy Memoires, zamieszczonym po tomie IV, zranienia klatki piersiowej również zostały wyszczególnione i prócz odnośnika do numeru strony - każdorazowo znaleźć tam można także krótki opis poruszanego $\mathrm{w}$ danym akapicie zagadnienia.

Hasło klatka piersiowa - zranienia ${ }^{75}$ kolejno obejmuje następujące tematy:

1. Tom II - „śmierć spowodowana krwawieniem po zranieniu płuca, omówienie przypadku, postępowanie w takich zdarzeniach" s. 151, zostały tu również włączone dwie obserwacje - s. 152, 154;

${ }^{71}$ Tamże, s. 264

72 R. Bielecki, Wielka Armia Napoleona, BELLONA, Warszawa 2004, s. 57.

${ }^{73}$ Bulletins de la Faculte de Medecine de Paris et de la Societe etablie dans son sein, t. V (1816-1818), Ed. Migneret, Paris 1818, s. 214.

74 D.J. Larrey, Memoires de chirurgie militaire et campagnes du baron D-J Larrey..., dz. cyt., t. IV, s. 258.

75 Tamże, s. 497. 
2. Tom III - „powierzchowne zranienia klatki piersiowej” - s. 79, „rana klatki piersiowej powikłana złamaniem mostka” - s. 80;

3. Tom IV - „rana klatki piersiowej powikłana obrzękiem podskórnym” - s. 11, „ciała obce w ranach klatki piersiowej i ich usunięcie” - s. 250, „obserwacja przypadku, w którym zaszła konieczność wycięcia całego żebra" - s. 253.

Jednak zdecydowanie najwięcej miejsca problemowi urazów klatki piersiowej Larrey poświęcił w drugim tomie swojej monografii i zarazem najobszerniejszego, obejmującego pięć tomów dzieła zatytułowanego Clinique chirurgicale... ${ }^{76}$. Jest to obszerna, licząca 161 stron pierwsza część rozdziału zatytułowanego Choroby chirurgiczne tułowia.

Zasadniczy temat został $\mathrm{w}$ nim podzielony na szereg mniejszych podrozdziałów i kolejno są to:

1) Niewyszczególniony w spisie treści krótki akapit: „proste zranienia penetrujące do klatki piersiowej" 77 , w którym omawia m.in. przypadek żołnierza zranionego w czasie ćwiczeń ostrzem floretu między trzecim a czwartym międzyżebrzem po stronie prawej. $Z$ rany wraz z krwią wydostawało się powietrze, ale nie było objawów przenikania go pod skórę i odmy. Rana została pokryta przylepca$\mathrm{mi}$, a dodatkowo jeszcze zabezpieczona opatrunkiem nasyconym maścią ze styraksu, popularnej podówczas maści do pokrywania $\operatorname{ran}^{78}$. W jej skład wchodziła żywica styrakowa ${ }^{79}$, która ze względu na dużą zawartość kwasu benzoesowego wykazywała pewne działanie antyseptyczne ${ }^{80}$. Cała kuracja zakończyła się pomyślnie po kilku tygodniach.

2) Dalsze części zostały już wyszczególnione i opatrzone oddzielnymi tytułami. Kolejno są to:

1. Rany penetrujace do klatki piersiowej wraz z uszkodzeniem naczyń, które znajduja się w jej ścianach - s. 179-187.

2. Rany płuc skomplikowane i powikłane odma - s. 188-198.

${ }^{76}$ J.D. Larrey, Clinique chirurgicale, exercée particulièrement dans les camps et les hôpitaux militaires, depuis 1792 jusqu'en 1829, t. I, IV, Ed. Gabon, Paris 1829, t. V, Ed. Balliere, Paris 1832.

77 D.L. Larrey, Clinique chirurgicale, exercée particulièrement dans les camps et les hôpitaux militaires, depuis 1792 jusqu'en 1829, t. II, s. 176-179.

${ }^{78}$ Przepisy lekarstw dla Szpitalów Woyska Polskiego. Dzieło tłomaczone z języka francuzkiego..., w Warszawie roku 1810, s. 87.

${ }^{79}$ Naturalna żywica pochodząca z drzew rosnących w Indiach i Azji Południowo-Wschodniej https://encyklopedia.pwn.pl/haslo/styrakowiec;3980904.html [dostęp: 16.04.2020].

${ }^{80}$ Polskie Towarzystwo Farmaceutyczne, Farmakopea Polska X, Urząd Rejestracji Produktów Leczniczych, Wyrobów Medycznych i Produktów Biobójczych, Warszawa 2014, s. 4276. 
Prócz wzmiankowanego w tej partii tekstu znajduje się również niewielki - obejmujący niecałą stronę - niewyszczególniony w spisie treści oddzielny akapit poświęcony obrażeniom klatki piersiowej, w przypadku których fragmenty tkanki płucnej wydostają się na zewnątrz rany;

3. Rany drażace do klatki piersiowej w przypadkach, gdy znajduje sie $w$ nich ciało obce - s. 199-220;

4. Rany klatki piersiowej powikłane wysiękiem, który ulega powolnej resorpcji-s. 221-237;

5. Rany klatki piersiowej, w których proces resorpcji wysięku nie następuje - s. 237-242;

6. Operacja ropniaków... - s. 242-280.

Każdej części tekstu oprócz opisu towarzyszą również obserwacje konkretnych przypadków odnoszące się do omawianych sytuacji klinicznych, które poczynił Larrey w czasie swojej wieloletniej pracy jako chirurg wojskowy.

Zakończenie stanowi sprawozdanie sporządzone przez dr. François Chaussiera, odczytane na posiedzeniu Academie Royale de Medecine 5 sierpnia 1822 r., a dotyczące praktycznego wykorzystania techniki Larreya w przypadku operacji ropniaków wikłających zranienie klatki piersiowej, którą zastosował u jednego ze swoich pacjentów w grudniu $1820 \mathrm{r} .{ }^{81}$ Została ona zgłoszona z pewnym opóźnieniem wynikłym z choroby autora i po zaprezentowaniu zaakceptowana do druku przez kolegium, w skład którego wchodzili: Philippe Joseph Pelletan, Pierre François Percy i wymieniony już François Chaussier.

Do wzmiankowanego tematu Dominique Jean Larrey powrócił jeszcze raz w czwartym tomie w rozdziale Szczegóty operacji wykonanych $w$ szpitalu Gros-Caillou ${ }^{82} u$ żotnierzy rannych $w$ czasie starć ${ }^{83}$, gdzie jeden z akapitów, liczący pięć stron, zatytułował: Rany penetrujace do klatki piersiowej - obserwacje ${ }^{84}$, w którym zaprezentował

${ }^{81}$ Tamże, s. 281 .

${ }^{82}$ Gros Caillou był podówczas jednym z większych szpitali wojskowych założonym w Paryżu przez księcia de Brion w 1759 r. Cieszył się zasłużenie wysoką renomą i - co należało wówczas do rzadkości - posiadał własne ujęcie wodne, obudowane później w 1806 r. wzniesioną na rozkaz Napoleona tzw. fontanną Marsa, z której udostępniano wodę pitną mieszkańcom miasta. Liczył 264 łóżka o dość różnym profilu, lecz podejmowane przez D.J. Larreya od 1802 r. działania dość szybko doprowadziły do przekształcenia Gros Caillou w prawdziwą i jak na owe czasy nowoczesną, klinikę chirurgiczną. Tu za: P. Valery Radot, Hôpital militaire de Gros Caillou de Henri IV a Louis Philipe (16021836), br. m. wyd. 1947, s. 127.

${ }^{83}$ J.D. Larrey, Clinique chirurgicale. Exercee particulierement dans le camps et les hôpitaux militaires depuis 1792 jusqu'en 1829, Ed. Balliere, Paris 1832.

${ }^{84}$ Tamże, s. 267-271. 
i omówił cztery przypadki ran postrzałowych penetrujących do klatki piersiowej i usytuowanych na ogół w górnej jej części. Zastosowane postępowanie, o którym niestety nie wspomina wiele, sprawiło, iż wszyscy czterej pacjenci przeżyli bez większych powikłań, jedynie u ostatniego, który został ranny z bardzo bliskiej odległości i gdzie doszło do złamania łopatki, utrzymywał się paraliz bark $u^{85}$.

W drugim tomie Clinique chirurgicale... Larrey zajął się również problemem ran serca. Tematykę tę ujął w dwóch oddzielnych, obszernych, liczących w sumie 53 strony akapitach zamieszczonych po rozdziale poświęconym urazom klatki piersiowej ${ }^{86}$. Kolejno były to:

1. Rany worka osierdziowego i serca - s. 284-303, gdzie m.in. podał oznaki wskazujące na zranienie osierdzia, zaliczając do nich: „kierunek rany $\mathrm{w}$ okolicy serca z przebiciem klatki piersiowej, równomierne wytryskiwanie jasnoczerwonej krwi w odstępach czasu zgodnych z biciem serca, zwiększenie uderzeń serca ze ściągniętym i przyspieszonym pulsem" ${ }^{87}$. Nie omieszkał przy tym zaznaczyć, że praktycznie nie pojawiają się pęcherzyki powietrza, tak charakterystyczne dla ran klatki piersiowej, gdzie doszło do uszkodzenia płuc;

2. Nowy sposób otwarcia worka osierdziowego w przypadku nagromadzenia sie płynu w jamie osierdziowej-s. 303-305.

W zakończeniu opisanym jako observations ${ }^{88}$ omówionych zostało kilka przypadków, w których ów sposób został zastosowany praktycznie.

Bezpośrednio z raną worka osierdziowego, gdy przyszło mu udzielić pomocy rannemu, Larrey zetknął się 18 marca $1810 \mathrm{r}^{89} \mathrm{u}$ 30-letniego żołnierza, który usiłował popełnić samobójstwo, wbijając sobie nóż $\mathrm{w}$ klatkę piersiową. W następstwie zranienia doszło też do uszkodzenia worka osierdziowego, w którym zaczął gromadzić się płyn wysiękowy. Na 11. dzień po incydencie Larrey naciął ścianę klatki piersiowej pomiędzy piątym a szóstym międzyżebrzem i następnie osierdzie w miejscu największego chełbotania, po czym uzyskał około litra płynu. Powtórzył ten zabieg po kilku dniach, znów uzyskując pewną ilość wydzieliny. Pierwszy pacjent, u którego dokonane zostało nakłucie worka osierdziowego, niestety zmarł po blisko dwóch miesiącach (21 maja $1810 \mathrm{r}$.), przypuszczalnie z powodu gorączki o charakterze tyfoidalnym.

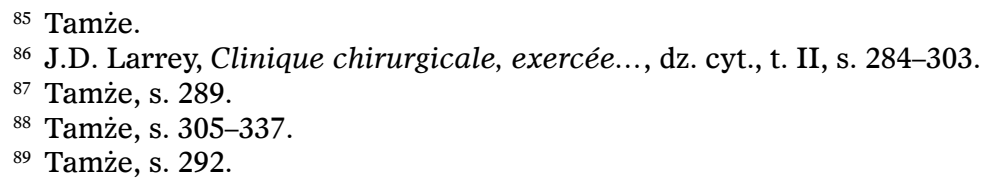


Przy analizie tego pierwszego przypadku wypada skierować uwage na coś jeszcze. Potocznie osłuchiwanie serca i płuc wiąże się z nazwiskiem Rene Laenneca, który nie tylko praktycznie wprowadził stetoskop, ale także poświęcił temu zagadnieniu swoje wydane w 1819 r. dzieło O ostuchiwaniu ${ }^{90}$. A był to sposób, którym przypuszczalnie od dawna posługiwali się szczególnie lekarze wojskowi. Wnioskiem może być następujący wers nakreślony przez Larrey: „nie wyczuwało się uderzeń serca na ścianie klatki piersiowej, zaś uchem pomagając sobie tubką zwinięta z kartki papieru można było zaledwie coś usłyszeć"91, dotyczący zdarzenia z 1810 r. i - o czym w dalszej części tekstu - w tymże samym roku opisanego.

Obserwacje poczynione podczas przeprowadzonej sekcji zwłok skłoniły Larreya do ustalenia i uściślenia wskazań do postępowania na przyszłość $\mathrm{w}$ podobnych przypadkach. Zgodnie z nimi nakłucie worka osierdziowego powinno być wykonywane w jego najniższej części rzutującej między podstawą wyrostka mieczykowatego a końcami siódmego i ósmego żebra po stronie lewej, gdzie istnieje niewielka szansa uszkodzenia któregoś z przyczepów przepony. Za podstawę swoich wywodów przyjął, że płyn będzie zbierać się w jego najniżej położonej części.

Punkt oznaczony przez niego do dziś jest miejscem dokonywania nakłucia worka osierdziowego ${ }^{92}$. Jest przy tym rzeczą niezwykle interesującą, że o możliwości wykonania takiego nakłucia w przypadku masywnego nagromadzenia się płynu przesiękowego w worku osierdziowym właśnie w okolicy dolnej krawędzi mostka wspominał w już połowie XVIII w. Jean Baptiste Senac w swojej pracy Traité de la structure du coeur, de son action et de ses maladies ${ }^{93}$, którego nazwiska co prawda Larrey nie wymienia (wspomina za to wybitnego włoskiego anatoma i chirurga Antonio Scarpa ${ }^{94}$, którego poznał osobiście podczas swojego pobytu we Włoszech ${ }^{95}$ ), lecz z tekstu można wywnioskować, iż dzieło to było mu dobrze znane.

${ }^{90}$ T. Różniatowski (red.), Mała encyklopedia medycyny, t. II, H-O, PWN, Warszawa 1988, s. 574-575.

${ }^{91}$ D. Larrey, Clinique chirurgicale, exercée..., dz. cyt., t. II, s. 295.

${ }_{92}$ H.G. Borst, W. Klinner, H. Oelert, Herzchirurgie. Die Eingriffe am Herzen und an Herznachen Gefäßen, „Springer Verlag”, Berlin Heidelberg 1991, s. 524.

${ }_{93}$ J.B. Senac, Traité de la structure du coeur, de son action et de ses maladies, Ed. J. Vincent, Paris 1749.

${ }_{94}$ D. Larrey, Clinique chirurgicale, exercée..., dz. cyt., t. II, s. 286.

${ }_{95}$ M.J. Turos, Dominique Jean Larrey. 1766-1842. Chirurg Wielkiej Armii, „Napoleon V”, Oświęcim 2017, s. 80. 
Warto w tym miejscu zaznaczyć, że pierwszą wzmiankę o przeprowadzonym przez siebie zabiegu Larrey zamieścił dużo wcześniej niż opisał na kartach Clinique chirurgicale..., a obydwa teksty, poza drobnymi detalami odnośnie do diety zastosowanej u pacjenta, są ze sobą bardzo zgodne. Pierwsze doniesienie ukazało się w roku 1810 na łamach Bulletin des Sciences Medicales ${ }^{96}$, wydawanym podówczas w Paryżu organie Societe Medicale d'Emulation de Paris, na którego czele stał Jean-Nicolas Corvisart. Informacje o technice, która została wówczas zastosowana, musiały dotrzeć również do Polski, gdyż Józef Czekierski w drugim tomie swojej Chirurgii ${ }^{77}$ w paragrafie 20., zatytułowanym w spisie treści Te operacyia przedsiębrano także $w$ wezbraniu wody pomiędzy sercem a workiem sercowym (Hydrops pericardii) ${ }^{98}$, podaje jako sposób dotarcia do worka osierdziowego celem wypuszczenia nagromadzonego $\mathrm{w}$ nim płynu cięcie pomiędzy piątym a szóstym żebrem po stronie lewej, czyli pierwotny sposób podany przez Larreya.

Tabela 1. Urazy worka osierdziowego opisane przez Dominika Jeana Larreya

\begin{tabular}{|l|l|l|l|l|}
\hline $\begin{array}{l}\text { Przy- } \\
\text { padek }\end{array}$ & Wiek & $\begin{array}{c}\text { Data } \\
\text { zranienia }\end{array}$ & \multicolumn{1}{|c|}{$\begin{array}{c}\text { Czym dokonano? } \\
\text { Miejsce zranienia }\end{array}$} & \multicolumn{1}{|c|}{$\begin{array}{c}\text { Wyniki } \\
\text { odlegle }\end{array}$} \\
\hline 1. & 28 lat & 23.01 .1824 & $\begin{array}{l}\text { rana postrzałowa - okolica } \\
\text { przedsercowa centralnie }\end{array}$ & wyzdrowienie \\
\hline 2. & $\begin{array}{l}\text { brak } \\
\text { danych }\end{array}$ & $\begin{array}{l}\text { grudzień } \\
1819\end{array}$ & $\begin{array}{l}\text { rana kłuta - przebicie klatki } \\
\text { piersiowej na wylot między } \\
\text { dolną krawędzią topatki } \\
\text { a 7-8 międzyżebrzem } \\
\text { po stronie lewej }\end{array}$ & wyzdrowienie \\
\hline 3. & 42 lata & 28.02 .1824 & $\begin{array}{l}\text { rana kłuta - pomiędzy most- } \\
\text { kiem a końcem 7 żebra }\end{array}$ & wyzdrowienie \\
\hline 4. & $\begin{array}{l}\text { brak } \\
\text { danych }\end{array}$ & brak \\
danych & $\begin{array}{l}\text { rana postrzałowa w okolicach } \\
\text { 6 żebra }\end{array}$ & zgon \\
\hline 5. & $\begin{array}{l}\text { brak } \\
\text { danych }\end{array}$ & 17.07 .1823 & $\begin{array}{l}\text { rana kłuta - okolica 7-8 żebra } \\
\text { po stronie lewej }\end{array}$ & zgon \\
\hline 6. & $\begin{array}{l}\text { brak } \\
\text { danych }\end{array}$ & 26.07 .1826 & $\begin{array}{l}\text { rana kłuta - w centralnej czę- } \\
\text { ści nadbrzusza }\end{array}$ & wyzdrowienie \\
\hline
\end{tabular}

Źródło: zestawienie sporządzone na podstawie danych Dominika Jeana Larreya zawartych w drugim tomie Clinique chirurgicale...

${ }^{96}$ Notice sur une blessure du pericarde suivie d'hydro-pericarie par M. le docteur Larrey chirurgien en chef Garde Imperiale et Royale, „Bulletin des Sciences Medicales", t. VI, Paris 1810, s. 255-268.

${ }_{97}$ Chirurgii przez Józefa Czekierskiego, t. II w Warszawie w Drukarni na Nowolipiu 1818, s. 37.

${ }^{98}$ Tamże, spis treści strony nienumerowane. 
Po opisie nowej metody Larrey, o czym zostało już wspomniane, omówił sześć kolejnych przypadków zaczerpniętych z własnej praktyki i pochodzących z lat 1819-1826, gdzie doszło do zranienia worka osierdziowego, a przypuszczalnie i powierzchni serca. Czterech rannych przeżyło, dwóch zmarło.

Szczególnie interesujący jest przypadek zranienia żołnierza, do którego doszło 28.02.1824 r. Była to rana kłuta zadana ostrym przedmiotem umiejscowiona ,pomiędzy mostkiem a końcem chrząstki 7 żebra po stronie lewej"99, która drążyła w nieustalonym kierunku ku górze. W czasie pierwszego sondowania z rany wypłynęła dość duża ilość krwistego płynu i początkowo ciężki stan pacjenta szybko zaczął się poprawiać. Podczas powtórnego sondowania „miękką sondą”, którego dokonał nie tylko sam Dominique Jean Larrey, ale również zabieg ten powtarzali bezpośrednio współpracujący z nim lekarze „Ribes, Gask i Cornak" (ich imion niestety nie podaje, co utrudnia identyfikację jedynie o pierwszym z nich wiadomo coś więcej, otóż był to François Ribes, asystent Larreya podczas kampanii $1813^{100}$, o którym zresztą pisze także w i tym tekście „mój przyjaciel”101), każdorazowo można było wyczuć uderzenia serca i „podczas tych czynności stwierdzało się puls mniejszy i przyspieszony"102. Wysięk stopniowo ustał i po 16 dniach zdjęto opatrunek, a po 46 od zaistniałego zdarzenia zupełnie wyleczonego pacjenta zaprezentowano podczas jednego z posiedzeń naukowych w Akademii Chirurgicznej ${ }^{103}$.

Należy zaznaczyć, że przypadek ten skłonił do podjęcia przez Larreya kilkakrotnych badań przeprowadzanych na zwłokach, które pozwoliłyby dokładnie określić punkt, w którym przy wniknięciu ostrego przedmiotu między kąt mostka a przyczep siódmego żebra, dojdzie do uszkodzenia worka osierdziowego, co jeszcze bardziej upewniło go w trafności ustalenia punktu wykonywania nakłucia.

Relacjonując swoje doświadczenia, Larrey odnotowywał również inne ciekawe doniesienia $\mathrm{z}$ posiedzeń Królewskiego Towarzystwa Medycznego. Na jednym z nich w 1823 r. zostało zademonstrowane serce mężczyzny zmarłego z powodu zapalenia otrzewnej, co stanowiło główny temat posiedzenia. Na sercu znajdowały się dwie blizny,

${ }^{99}$ D. Larrey, Clinique chirurgicale, exercée..., dz. cyt., t. II, s. 315.

${ }^{100}$ B. Veselle, G. Veselle, Sur les traces du docteur François Ribes, chirurgien de la 1ère division d'ambulance dite du champ de bataille, „Histoire des Sciences Medicales" 2014, t. XLVIII, nr 3, s. 407.

${ }^{101}$ D. Larrey, Clinique chirurgicale, exercée..., dz. cyt., t. II, s. 320.

102 Tamże.

103 Tamże, s. 321. 
$\mathrm{w}$ tym jedna $\mathrm{u}$ podstawy worka osierdziowego. Stanowiły one efekt ran odniesionych $\mathrm{w}$ bójce przed kilku laty. Niestety nie było wiadomo, kto wówczas udzielił pomocy rannemu, a był to jeden z paryskich tragarzy, ani jaki był przebieg leczenia. Zdarzenie to, tak starannie zrelacjonowane przez Larreya, wskazuje, że z tego typu obrażeniami lekarze paryscy musieli się stykać przypuszczalnie dość często. Jeśli pacjenci pochodzili z niższych warstw społecznych, a sam medyk nie zasiadał w naukowym gremium bądź nie miał tam kolegów, przekazanie informacji o tego rodzaju przypadkach było praktycznie niewykonalne. Statystyka Larreya pochodziła ze szpitala wojskowego, gdzie skrupulatnie przestrzegano ewidencjonowania rannych czy chorych żołnierzy.

W tym miejscu wypada postawić pytanie, czy Dominique Jean Larrey był pierwszym lekarzem, który dokonał nakłucia worka osierdziowego w przypadku nagromadzenia się w nim płynu. Otóż nie wcześniej działanie takie podjął hiszpański, a według Harrisa Schumackera ${ }^{104}$ i Alejandra Arisa ${ }^{105}$ kataloński medyk Francisco Romero, absolwent fakultetu medycznego w Aragonii. Dokonał tego najprawdopodobniej w $1801 \mathrm{r}^{106} \mathrm{w}$ Almerii - małym miasteczku w Andaluzji.

Warto więc postawić następne pytanie, czy Dominique Jean Larrey mógł osobiście poznać Francisco Romero? Tu do nauki niestety wkracza polityka. Podczas pierwszego pobytu w Hiszpanii w 1808/1809 r., kiedy przebywał w Madrycie oraz na północy kraju, z powodu swoich obowiązków praktycznie nie miał możliwości utrzymywania bliższych kontaktów z hiszpańskim środowiskiem medycznym, choć o takich stosunkach wspominat ${ }^{107}$. Kiedy natomiast we wrześniu 1812 r. wojska francuskie wycofywały się z południowej Hiszpanii i wraz z nimi Francisco Romero przyjechał do Pary$\dot{z} \mathrm{a}^{108}$, był on o blisko $3000 \mathrm{~km}$ na wschód od kraju - w okolicach bądź w samej Moskwie. Gdy zaś 7.06.1815 r. Romero przedstawiał swoją pracę Observatio experimentis confirmata pro hydrope pectoris, pulmonum anasarca, et hydropericardio cognoscendis, et nova metho-

\footnotetext{
${ }^{104}$ H.B. Shumacker, When did cardiac Surgery begin?, "Journal of Cardiovasc. Surg” 1989, nr 30, s. 246-249.

${ }^{105}$ A. Aris, Francisco Romero, the First Heart Surgeon, „Ann. of Thor. Surg” 1997, nr 64, s. 870.

106 J. VanThielen, R. Van Hee, Pericardiotomy: the First Cardiac Operation, "Acta Chir. Belgica” 2008, nr 108, s. 133.

107 Tu P. Triaire, Dominique Larrey et les campagnes de la révolution et de l'Empire, 1768-1842, Ed. Mame, Tours 1902 s. 458-468.

${ }^{108}$ A. Aris, dz. cyt., s. 870.
} 
dus dictos morbos operandi ${ }^{109}$ na posiedzeniu Societe de l'Ecole de Medecine" ${ }^{110}$. Larrey wraz ze zorganizowanymi przez siebie ambulansami wędrował za armią na północ Francji. Dziesięć dni później doszło do batalii pod Waterloo. A później, po bitwie, gdy cudem uniknął rozstrzelania, znalazł się na liście proskrypcyjnej i groziła mu nawet kara śmierci. Po zmianie wyroku praktycznie przez dwa bądź nawet trzy lata znajdował się pod ścisłym nadzorem żandarmeriii ${ }^{111}$. $\mathrm{Z}$ całą pewnością nie mógł uczestniczyć w normalnym życiu akademickim Paryża, tym bardziej że wyrokiem komisji, przed którą był zmuszony stanąć 27.11.1815 r., został uznany za nieposiadającego właściwych kwalifikacji lekarskich do pełnienia jakichkolwiek funkcji w szpitalach wojskowych ${ }^{112}$. Dopiero w $1816 \mathrm{r}$. wolno mu było powrócić do pracy w szpitalu Gros Caillou ${ }^{113}$. On sam również nie wspominał, aby nawiązał kontakt z Romero.

Ów wpływ polityki widać również w artykule Victora Merat de Vaumartoise'a zamieszczonym w 1819 r. w kolejnym tomie Dictionnaire des sciences médicales ${ }^{114}$, w którym metoda i działania Francisco Romero zostały szczegółowo opisane wraz z odpowiednimi cytatami, a o Larreyu jest zaledwie wers wzmianki, że dokonał nakłucia osierdzia, bez adnotacji o opublikowanym w 1810 r. tekście. Warto zaznaczyć, że na tę niespójność zwrócił uwagę John Bingham Roberts $\mathrm{w}$ swojej monografii Paracentesis of the pericardium. A consideration of the surgical treatment of pericardial effusions ${ }^{115}$, pisząc, iż tak samo jak z punktu widzenia nauki cenne jest doniesienie Romero, są również cenne informacje Larreya czy nawet Desaulta ${ }^{116}$.

Podobnie w biuletynie zamieszczającym doniesienia z posiedzeń Faculte de Medecine w Paryżu jest tylko zaznaczone nazwisko, bez podania pełnego tytułu wystąpienia zgłoszonego na posiedzenie 22.08.1816 r., ani tym bardziej nie ma informacji, że zostało zapla-

${ }^{109}$ F. Romero, Observatio experimentis confirmata pro hydrope pectoris, pulmonum anasarca, et hydropericardio cognoscendis, et nova methodus dictos morbos operandi, Ed. Jeunhomme, Paris 1815.

110 Tamże.

${ }^{111}$ P. Triaire, dz. cyt., s. 665.

112 M. Genty, Jean - Dominique Larrey. Quelques documents inedites, „Le Progres Medical” Suppl. 1930, R. VI, nr 1, s. 6.

113 M.J. Turos, Dominique Jean Larrey (1766-1842)..., dz. cyt., s. 222.

114 „Dictionnaire des sciences médicales” Une Societe de Medecins et Chirurgiens, t. 40 (PEC - PERO) Paris, Panckoucke 1819, s. 369-375.

115 J.B. Roberts, Paracentesis of the pericardium. A consideration of the surgical treatment of pericardial effusions, B. Lippincott \& Co, Philadelphia 1880, s. 39.

116 Tamże. 
nowane do druku ${ }^{117}$. Cytowana wzmianka jest niezwykle lakoniczna, zamykająca się praktycznie w dwóch wersach, ale zmusza do zastanowienia. Czy nie jest to jeszcze jedna, pomyślnie zakończona kuracja rany klatki piersiowej przeprowadzona przez Larreya? Od 1810 r. upłynął już pewien okres, więc czy cytowałby raz jeszcze znany i opublikowany tekst? Statystyka z Gros Caillou zaczyna się w latach 20, zatem przypuszczalnie był to przypadek z 1814 r., a może pomimo nadzoru policyjnego spieszył z pomocą medyczną mieszkańcom Paryża.

Wypada zadać jeszcze jedno pytanie. Czy po upływie ponad 200 lat aż tak bardzo jest istotne, kto był pierwszy? W pracy naukowej jakże często sprawdzają się słowa Czesława Miłosza, które zanotował w swoich esejach Widzenia nad zatoka San Francisco. Warto je zacytować: „nasza praca przypomina pracę prządki, a myśli wysnute przez poprzedników nie giną”"118. Pierwszy wysnuł ową nić „myśli”, jak pięknie napisał polski noblista, ów Hiszpan Francisco Romero, po nim, a może raczej równolegle, dołączył swoją Francuz - Dominique Jean Larrey.

I tylko trochę żal, że najczęściej w gronie pionierów kardiochirurgii wymienia się tylko Daniela Hale Williamsa oraz Ludwika Rehna ${ }^{119}$, a o Polakach, jak chociażby o Borzymowskim ${ }^{120}$, zupełnie nie wspominając. Przed wzmiankowaną dwójką byli również i inni...

\section{Bibliografia}

Aris A., Francisco Romero, the First Heart Surgeon, „Ann. of Thor. Surg” 1997, nr 64.

Bidloo G., Opera omnia anatomico-chirurgica, S. Luthmans, Lugduni Batavorum 1715.

Bielecki R., Wielka Armia Napoleona, BELLONA, Warszawa 2004. Borst H.G., Klinner W., Oelert H., Herzchirurgie. Die Eingriffe am

Herzen und an Herznachen Gefäßen, „Springer Verlag” Berlin Heidelberg 1991.

${ }^{117}$ Larrey zgłosił o operacji jaka dokonat przy okazji zranienia kula klatki piersio$w e j$, „Bulletins de la Faculte de Medecine de Paris”, t. V (1816-1815), Ed. Migneret, Paris 1818, s. 214.

118 Cz. Miłosz, Widzenia nad Zatoka San Francisco, „GŁOS”, Warszawa 1980 br. paginacji.

${ }^{119}$ L.H. Cohn, L.H. Edmunds, Cardiac Surgery in the Adult, McGraw-Hill Medical Publishing Division, New York 2003, s. 3.

${ }^{120}$ W. Kawalec, J. Kuc, J. Skalski (red.), Polskie szkoły kardiologiczne - kardiochirurgiczne - kardiologii dziecięcej, Wydawnictwo Naukowe PWN, Warszawa 2008. 
Bulletins de la Faculte de Medecine de Paris, t. V (1816-1815), Ed. Migneret, Paris 1818.

Bulletins de la Faculte de Medecine de Paris et de la Societe etablie dans son sein, t. V (1816-1818), Ed. Migneret, Paris 1818.

Chirurgii przez Józefa Czekierskiego, t. II w Warszawie w Drukarni na Nowolipiu 1818.

Cieślik E., Turcza K., Właściwości prozdrowotne aloesu zwyczajnego Aloe vera (L.) Webb. (Aloe barbadensis Mill), „Postępy Fitoterapii” 2015, nr 2(16).

Cohn L.H., Edmunds L.H., Cardiac Surgery in the Adult, McGraw-Hill Medical Publishing Division, New York 2003.

Cook Ch., Stevenson J., Leksykon nowożytnej historii Europy 1763-1999, Warszawa 2000.

Czekierski J., Chirurgii przez Jóżefa Czekierskiego, t. II, Drukarnia przy Nowolipiu, Warszawa 1818.

Czerwiakowski R.J., Narzadu powszechnego opatrzenia chirurgicznego część III, Kraków 1816.

Dible J.H., Napoleon's Surgeon, „William Heinemann Medical Books”, London 1970.

Dictionnaire des sciences médicales, Une Societe de Medecins et Chirurgiens, t. 40 (PEC - PERO), Paris, Panckoucke 1819.

Dolara P., Analgesic effects of myrrh, „Nature” 1996, nr 379(6560).

Encyclopédie méthodique, chirurgie, par M. de La Roche et M. Petit-Radel, A-KYS, Panckoucke, Paris 1790, LAC-ZIG. Table des matières, explications des planches, Panckoucke, Paris 1792.

Encyclopédie méthodique, chirurgie, par une société de médecins. Recueil des planches du dictionnaire de chirurgie Paris : H. Agasse, An VII. (1799).

Estreicher K., Bibliografia polska XIX wieku, t. III, wyd. II, Drukarnia Narodowa, Kraków 1963.

Farmakopea Polska X. Urząd Rejestracji Produktów Leczniczych, Wyrobów Medycznych i Produktów Biobójczych, Warszawa 2014.

Genty M., Jean - Dominique Larrey. Quelques documents inedites, „Le Progres Medical” Suppl. 1930, R. VI, nr 1.

Grzelak E. (opr.), Chirurgia praktyczna Rafała Józefa Czerwiakowskiego, wyd. MON, Warszawa 1969.

Kluj P., Dąbrowski M., Sanak T., Dąbrowska A., Sip M., Gaszyński T., Specyfika udzielania pomocy medycznej poszkodowanemu w warunkach bojowych $w$ środowisku taktycznym w oparciu o standard TCCC Część IV: Zaopatrywanie obrażeń klatki piersiowej podczas wykony- 
wania zabiegów ratowniczych $w$ środowisku taktycznym $w$ oparciu o standard TCCC, „Anestezjologia i Ratownictwo” 2014, nr 8.

La practique et chirurgie de M. Iean de Vigo docteur en medecine. Divisé en deux parties: où est traicté la Cure des playes, ulcères, apostemes, \& autres maladies, desquelles le corps humain est souvent affligé. Traduict de latin en françois, par M. Nicolas Godin D. en médecine. Le tout de nouveau reveu, \& exactement corrigé, Pierre Rigaud, Lyon 1610.

Larrey J.D., Clinique chirurgicale, exercée particulièrement dans les camps et les hôpitaux militaires, depuis 1792 jusqu'en 1829, t. I-IV, Ed. Gabon, Paris 1829, t. V, Ed. Balliere, Paris 1832.

Larrey D.J., Chirurgische Klinik eine Sammlung in den Feldzügen und Militärhospitä,lern von 1792 bis 1829, t. I, Leipzig und Darmstadt 1831.

Mabberley D.J., Mabberley's Plant-Book, Cambridge University Press, Cambridge 2017.

Mémoires de l'Académie royale de chirurgie, Ed. Delaguette, Paris 1753.

Mémoires sur les parties sensibles et irritables du corps animal. Contenant les experiences de plusieurs anatomistes d'Allemagne, de France, d'Angleterre \& d'Italie. Ouvrage qui sert de suite aux mémoires de Monsieur de Haller, Sigismond d'Arnay, Lousanne 1760.

Miłosz Cz., Widzenia nad Zatoka San Francisco, „GŁOS”, Warszawa 1980.

Narzadu powszechnego opatrzenia chirurgicznego część VII. Tabele przez Rafała Czerwiakowskiego, br. m. wyd. br. daty.

Notice sur une blessure du pericarde suivie d'hydro-pericarie par M. le docteur Larrey chirurgien en chef Garde Imperiale et Royale, „Bulletin des Sciences Medicales”, t. VI, Paris 1810.

Perzyna L., Nauki cyrulickiey krótko zebraney..., w Drukarni J.O.Xcia PrymasaArcy-Biskupa Gnieźnieńskiego, w Kaliszu 1793, t. III.

Petit J.L., Traité des maladies chirurgicales : et des opérations qui leur conviennent, Ed. Méquignon l'aîné, Paris, 1790.

Polskie szkoły kardiologiczne - kardiochirurgiczne - kardiologii dziecięcej, red. W. Kawalec, J. Kuch, J. Skalski, Wydawnictwo Naukowe PWN, Warszawa 2008.

„Przepisy lekarstw dla Szpitalów Woyska Polskiego. Dzieło tłomaczone z języka francuzkiego..." w Warszawie roku 1810.

Ravaton H., Chirurgie d'armée ou traité des plaies d'armes à feu, et d'armes blanches, Ed. Didot, Paris 1768. 
Relation historique et chirurgicale de l'armee d'Orient en Egypte et en Syrie par D-J. Larrey, Ed. Demonville et soeurs, Paris 1803.

Roberts J.B., Paracentesis of the pericardium. A consideration of the surgical treatment of pericardial effusions, B. Lippincott \& Co, Philadelphia 1880.

Romero F., Observatio experimentis confirmata pro hydrope pectoris, pulmonum anasarca, et hydropericardio cognoscendis, et nova methodus dictos morbos operandi, Ed. Jeunhomme, Paris 1815.

Różniatowski T. (red.), Mała encyklopedia medycyny, t. II H-O, PWN, Warszawa 1988.

Rumebe de Suech E., Dissertation sur les plaies d'armes a feu penetrantes dans la poitrine, Ed. Didot Jeune, Paris 1814.

Sabatier R.B., De la médecine opératoire, t. I, Ed. Bechet Jeune, Paris 1822.

Sabatier R.B., De la médecine opératoire, t. II, Ed. Bechet Jeune, Paris 1824.

Senac J.B., Traité de la structure du coeur, de son action et de ses maladies, Ed. J. Vincent, Paris 1749.

Shumacker H., When did cardiac surgery begin?, „Journal of Cardiowasc. Surgery" 1989, nr 30.

Stembrowicz W., Dominique Jean Larrey (1766 - 1842) - autor pracy o ranach worka osierdziowego, „Archiwum Historii i Filozofii Medycyny" 1995, nr 58, z. 3.

Toth I., Rami-Porta R., Rendeki Sz., Molnar T.F., First steps in the Management of Pericardial Effusion: Who Was the First to Relieve the Pericardial Sac - Larrey or Romero, „World Journal of Surgery” 2013, nr 37.

Triaire P., Dominique Larrey et les campagnes de la révolution et de l'Empire, 1768-1842, Ed. Mame, Tours 1902.

Turos M.J., Dominique Jean Larrey (1766-1842), „Napoleon V”, Oświęcim 2017.

Turos M.J., Człowiek, któremu mogłem zaufać (Napoleon Bonaparte). Jan Dominik Larrey i jego misja w czerwcu 1813 roku, w: Studia nad epoka napoleońska, t. I, „Napoleon V”, Oświęcim 2014.

Valentin L-A., Recherches critiques sur la chirurgie moderne, avec des lettres à M. Louis, ... docteur en chirurgie... secrétaire perpétuel de l'Académie royale de chirurgie", Amsterdam 1772.

Valery Radot P., Hôpital militaire de Gros Caillou de Henri IV a Louis Philipe (1602-1836), br. m. wyd. 1947. 
VanThielen J., Van Hee R., Pericardiotomy: the First Cardiac Operation, „Acta Chir. Belgica” 2008, nr 108.

Veselle B., Veselle G., Sur les traces du docteur François Ribes, chirurgien de la 1ère division d'ambulance dite du champ de bataille, „Histoire des Sciences Medicales” 2014, t. XLVIII, nr 3.

Vicq-d'Azyr F., Encyclopédie méthodique, médecine, par une société de médecins. CO-ENV, Ed. Pancoucke, Paris 1792.

\section{Strony internetowe}

http://gallica.bnf.fr/ark:/12148/bpt6k9690743x.

https://pl.wikipedia.org/wiki/Karuk.

https://ptkt.pl/historia-polskiej-kardiochirurgii/.

https://kardiochirurgiadziecieca.cm-uj.krakow.pl/historia/wazne-daty -historyczne-w-kardiologii.

https://encyklopedia.pwn.pl/haslo/styrakowiec;3980904.html. 